\title{
LABOUR MARKET REQUIREMENTS FOR FOREIGN LANGUAGE EDUCATION WITH A FOCUS ON SPANISH
}

\author{
Mária Spišiaková, Zuzana Kittová \\ University of Economics in Bratislava, Bratislava, Slovakia \\ maria.spisiakova@euba.sk; zuzana.kittova@euba.sk
}

\begin{abstract}
The paper focuses on education in the field of foreign languages, particularly Spanish, in the framework of university study of economic and managerial orientation in Slovakia in order to find out what the labour market requirements are for graduates in the field of foreign language skills. In our research, we focus on Spanish, as no similar relevant research has been done to date in this foreign language. Current research shows that the graduates of economics and management fields lack the link between the content of education and the requirements of the labour market, as well as preparation in the field of foreign language skills. This calls for a better understanding of the real needs of employers and graduates. This paper is based on a questionnaire survey among potential employers of graduates of the University of Economics in Bratislava who require foreign language skills, mainly Spanish, as well as of graduates of the University of Economics in Bratislava who use foreign languages, in particular Spanish in their employment.

The paper provides an overview of the specific language competencies and knowledge that are needed in the labour market. The ambition of research is to contribute to improving the link between higher education content and the real needs of the labour market, and thus to boosting the employability of graduates in the labour market.
\end{abstract}

Keywords: Spanish; foreign language; education; labour market.

\section{Introduction}

The University of Economics in Bratislava (EU BA) plays a key role in higher education in economics and management in Slovakia. It is the only public university in Slovakia specialising in this field of education. At the same time, it produces the highest number of graduates in Economics and Management in Slovakia, when the total number of its graduates has exceeded 100,000 since the establishment of the university in 1940 (University of Economics in Bratislava, 2018). In particular, the mission of the EU BA is to provide quality higher education in three stages of higher education in a complex of economic and managerial programmes and selected study programmes in the field of humanities and informatics' (Sivák et al., 2010, p. 70). Increased attention is paid to the creation of curricula and curricula of individual subjects in order to reflect the requirements of social and economic practice. In this paper, we focus specifically on the education of university students of economic and managerial study programmes in the field of foreign languages with a focus on Spanish.

\section{Literature review}

So far, according to our findings, no similar research has been carried out in Slovakia or abroad for Spanish. The existing literature on teaching Spanish as a foreign language, especially business Spanish, addresses various aspects of teaching, with at least a few examples. Garcia Brenes (2000, p. 421) uses an interdisciplinary approach and suggests a way to master language and culture in the context of international business. Attention is drawn to contemporary literary texts dealing with social, historical, cultural or political topics that can be used in teaching business Spanish as well as international business. According to the author, literature is a rich source of information from which students gain knowledge. Montanes Mesas (2017, p. 224) emphasise the importance of creativity in teaching business Spanish. According to them, students learn better if the task is interesting to them or evokes emotions. They generally distinguish between two kinds of creative tasks: those that require computer programmes and others that are rhetorical or literary. Rodriguez Cachon (2016, p. 225) is dedicated to creating online written exercises designed to teach Spanish as a foreign language at universities. He makes specific recommendations which take into account the determined requirements arising from this type of exercise. López Perez (2013, p. 156) offers a theoretical framework for choosing vocabulary useful for teaching Spanish as a second language when students need to acquire not only the ability to communicate in this foreign language but also to master the academic language. De la Vega (2016, p. 179) points out the benefits of using Project-Based Learning in business Spanish teaching. Sánchez $(2014$, p. 59) examines the history of teaching Spanish as a foreign language in Europe.

In Slovakia, there are not similar studies on Spanish language and its application and utilisation in practice. There are some articles about English, for example, Hrdličková (2019, p. 67) who looks at what 
knowledge Slovak undergraduates should demonstrate regarding small business management or Rusiňáková (2018, p. 48) who examines current phraseology in the field of economics and develops the students' reading literacy as well as their speaking skills with the focus on idioms used in professional settings. The contemporary business Spanish is analysed by Spišiaková (2018, p. 42) or Ulašin (2016, p. 28). Varela Cano (2016, p. 153) focuses on the improvement of communicative skills in business Spanish. In the area of Romance languages, we can mention Rizeková (2018, p. 150), she refers to the teaching French at the University of Economics.

In the international context, we can find some studies on business language, language in management or intercultural aspects of language, for example, Abregova et al. (2018), Novikova et al. (2017), Tareva et al. (2017).

If we want to address the requirements for preparing university students of economic and managerial study programmes in the field of foreign languages, especially Spanish, it is necessary to start with the conclusions of studies that examined the readiness of university graduates in Economics and Management in Slovakia for labour market requirements. Čiefová and Séresová $(2017$, p. 21) studied whether real foreign language knowledge of the EU BA graduates meets the requirements of the labour market, and whether the curricula of individual subjects reflect these requirements. They highly recommend students to acquire at least basic knowledge of German in order to increase their competitive advantage.

Lesáková, Dzimko and Farkašová $(2012$, p. 2) conducted research aimed at evaluating the theoretical and practical training of university students for the labour market, finding out the level of students' generic competencies, assessing the consistency of the acquired education and labour market requirements, strengths and weaknesses in the preparation of graduates and their placement in the labour market. They concluded that $56 \%$ of university graduates in Economics and Management in Slovakia evaluated the acquired theoretical knowledge positively. However, up to $66 \%$ of graduates had a low level of skills required by the labour market. In terms of the usefulness of the knowledge acquired during the studies, up to $56 \%$ of the graduates from Economics and Management graduates in Slovakia used less than $40 \%$ of it. In the assessment of foreign language skills acquired during their studies, $45 \%$ of graduates evaluated this knowledge positively.

Baláž et al. (2012, p. 66) investigated the employment of graduates of engineering and doctoral studies at the Faculty of Business of the EU BA in order to improve the quality of their training. According to their conclusions, more than half of the graduates of engineering studies consider education at the Faculty of Business of the EU BA as sufficient and satisfying the requirements of practice. However, up to $48 \%$ consider it insufficient. A total of $76 \%$ of graduates use or partially utilise the knowledge they acquired during their engineering studies. The authors of the study state that although engineering studies can reflect on the needs of practice, it is still not enough. The most frequently reported shortcoming of engineering graduates was the lack of foreign language skills. The graduates in practice lacked the knowledge of foreign languages.

The portal www.lepsieskoly.eu offers detailed information concerning directly or indirectly the employability of Slovak university graduates in the labour market. As regards EU BA graduates from 2008 to $2014,68 \%$ of graduates consider study as a good basis for finding employment in the labour market. The competencies acquired during the study are evaluated on a 10-point scale $(1=$ very low to $10=$ very high $)$, with 26 competencies being evaluated. On average, the highest ranked competencies of EU BA graduates include the ability to learn and organise their learning as well as the ability to work with information (average grade 7). Conversely, foreign language skills (average mark 4), ability to use professional knowledge in practice or ability to work in an intercultural environment (average mark 5) achieved the lowest rating.

The Deloitte company study (2018, pp. 6-20) provides an international comparison of the readiness of university graduates, particularly in Economics in 14 countries of Central and Southeastern Europe. It focuses on the experiences and abilities of students and graduates and their access to work. At the same time, it maps the areas that most worry them about graduates. According to this study, the main reason for concern for young people in Central Europe is the persistent perception of the lack of training for a professional life provided by universities. Only $16 \%$ of graduates evaluate the preparation for professional career provided by the university positively. These findings show that there is scope for closer cooperation between academics and business and improving the links between these "worlds".

From the above overview of findings, we can conclude that, with regard to graduates in Economics and Management (including EU BA graduates), it is necessary to strengthen the link between educational content and labour market requirements as well as foreign language training. 
This raises the need to identify labour market requirements in terms of foreign language readiness of university graduates. In response to this need, the aim of our paper is to find out the requirements of the labour market for graduates of economic and managerial studies in Slovakia in the field of foreign language skills, especially Spanish. The present research is by its nature a basic research in the field of higher education. It is based on a descriptive type of research problem that has been identified as follows: What knowledge and competencies should university graduates in economics and management in foreign languages, especially Spanish, have in order to meet labour market requirements? By considering the results of research in the content of education, research has the ambition to contribute to a better link between higher education and the needs of the labour market. This will facilitate the full exploitation of the potential of graduates for the benefit of their employers and of society.

\section{Methods}

In order to identify labour market requirements for university graduates in economics and management in Slovakia in the field of foreign language skills, we conducted a survey in the form of a questionnaire. The survey was conducted in the months of June - October 2018. The basic research sample consisted of all potential employers of graduates of the University of Economics in Bratislava requiring foreign language skills, especially Spanish, as well as EU BA graduates using foreign languages in their jobs, in particular Spanish. The sample consisted of companies in Slovakia cooperating with foreign entities operating in Spanish speaking countries (e. g. exporting to Spain or other Spanish speaking countries, importing from these countries, providing services, whether they are shared service centres, financial or consulting services) and graduates of the International Business EU BA degree (graduated from 2008 to 2016). In this way, we have obtained a sample that represents the requirements of economic practice for speaking foreign languages, especially Spanish. The sample size was 600 . Altogether, 63 respondents participated in the research.

According to the main activity carried out by enterprises, respectively organisations involved in the survey, most enterprises operate in the field of business and marketing (20.4\%), then in industrial production such as production and processing of metals, food, automotive, chemical industry and others (16.7\%), followed by the financial and banking sectors (13\%), information and telecommunications (13\%), and consulting and accounting (9.3\%). To a lesser extent, state and public administration, education and administration were represented (the share of each of these areas is at the level of $5-6 \%$ ). Finally, transport, logistics, construction and electricity distribution companies were individually represented.

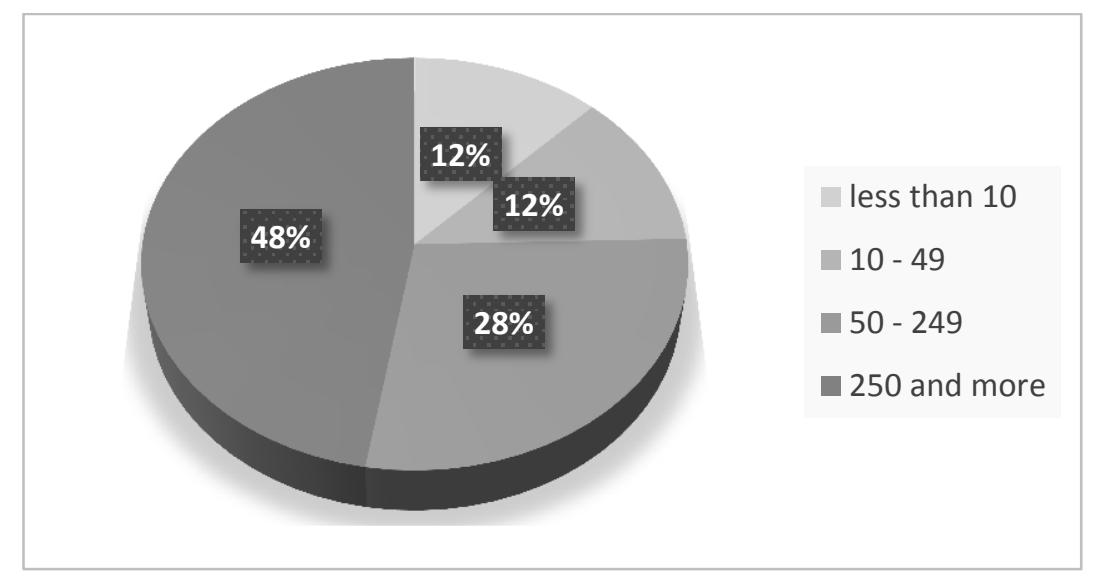

Figure 1. Sample structure by number of employees

We surveyed the size of the subjects involved in the survey based on the number of employees and turnover. Most enterprises were large and medium-sized enterprises. Large enterprises by the number of employees (250 and more) accounted for $48 \%$ of enterprises and by turnover (at least EUR 50 million) 46\%. Medium-sized enterprises by the number of employees (from 50 to 249) accounted for $28 \%$ and $13 \%$ of enterprises by turnover (from 10 to 50 million EUR). Figures 1 and 2 provide more detailed information. 


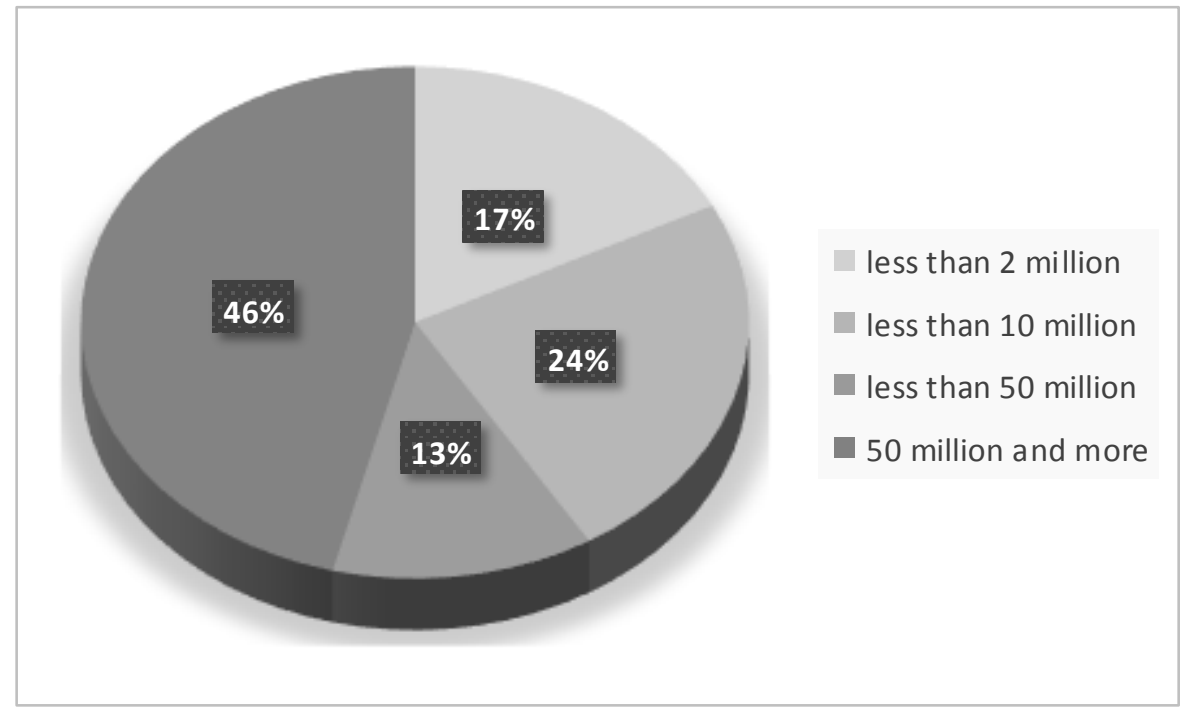

Figure 2. Sample structure by turnover size (in EUR)

The characteristics of entities involved in the survey by ownership are as follows: enterprises without foreign equity participation accounted for $32 \%$, enterprises with foreign equity participation $65 \%$, the rest were entities with other ownership.

From the geographical point of view (based on the main place of work according to the number of employees), all regions of Slovakia except one (namely Trenčín) were represented by the respondents. However, the Bratislava area, which is the most economically advanced province of Slovakia, was most represented $(86 \%)$.

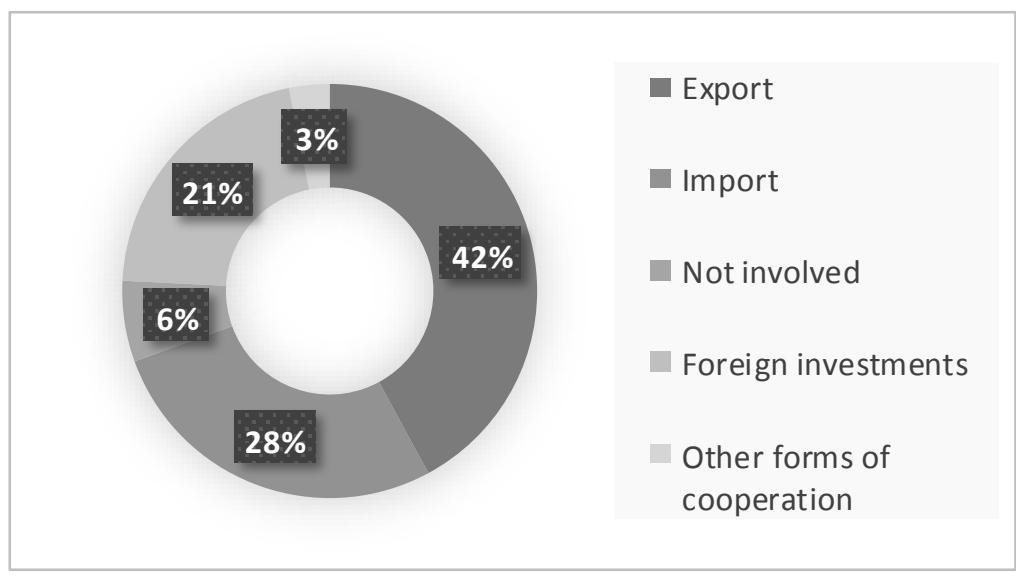

\section{Figure 3. Sample structure according to the method of involvement in international cooperation}

Exports and imports of goods and services dominate the ways in which entities are involved in international economic cooperation. Their share, as well as the shares of other forms of involvement, is shown in Figure 3. The category 'other forms of cooperation' in Figure 3 includes joint projects, state policy management, teacher and student mobility. Up to $79 \%$ of respondents carry out the bulk of international economic activities within the EU. Compared to macroeconomic data, this share corresponds to the EU share of Slovakia's foreign trade, which has long been more than 80\% (Kašt’áková \& Bebiaková, 2017).

\section{Results and discussion}

The survey focused on several thematic areas, namely: 1. the possibility of employment of EU BA graduates in the company or organisation, 2. the importance of speaking Spanish as a foreign language for economic practice in Slovakia, 3. the importance of individual language competencies and knowledge as well as the required level of foreign language skills, 4. assessing the language competencies of EU BA graduates and the expectations of their potential employers. The following section summarises the most important results for each area. 
The correctness of the selection of the sample was confirmed based on the evaluation of respondents' answers to 4 questions. We first investigated whether and how businesses engage in international economic cooperation. Up to $94 \%$ of the respondents were businesses engaged in international economic cooperation. We also investigated whether these companies cooperate with Spanish-speaking countries. Cooperation with at least one Spanish-speaking country was confirmed by $80 \%$ of the respondents. Spanish is used by $75 \%$ of respondents. Finally, $92 \%$ of the respondents stated the possibility of successful inclusion in the professional life of EU BA graduates.

\section{Employment of graduates of the University of Economics in Bratislava}

Firstly, we tried to find out whether the addressed companies, respectively organisations employ EU BA graduates. Only $8 \%$ of respondents stated that they did not find employment for the graduates. Almost half of all respondents confirmed their employment in sales, marketing and logistics. The second most frequent work placement for EU BA graduates was in the finance and accounting departments (37\% of respondents). This was followed by management and project management (24\%), administration (14\%), analytical positions (10\%). EU BA graduates can also find employment in human resources area, as consultants or IT staff. 8\% of respondents even stated that EU BA graduates can have job placement in all work positions within the company.

\section{The importance of speaking Spanish as a foreign language in Slovakia}

The importance of speaking Spanish as a foreign language is related to the economic characteristics of Slovakia. Slovakia, as a member of the European Union, is one of the dynamically developing countries of Central and Eastern Europe, characterised by a small economic size and a high degree of openness measured as a share of exports and imports in gross domestic product. This degree of openness has long been at $157 \%$ (Ružeková \& Kaštáková, 2018). The country's strong export orientation is also the basis of its economic growth. From a microeconomic point of view, the extent in which competitiveness of companies operating here is determined by the availability, qualifications and language skills of employees is not negligible. According to a study by the European Commission (2015) on examining labour market demand for foreign language skills in the EU-28, English is the most demanded language in these countries. The second foreign language is one of the following languages: Russian, German, French and Spanish. The importance of these foreign languages is given by the location of the most important business partners, whether customers or suppliers. A country's strong position in a foreign market or sector means a demand for employees who know the foreign language. This also applies to Slovakia. According to a survey of language proficiency of Grafton Slovakia (2017), first of all, an advanced level of English language skills is needed. This is due to the presence of many foreign companies offering job opportunities in this country. However, knowledge of English is often a minimum requirement, optimally knowledge of two foreign languages. Most often it is required with German, French, Italian, Spanish, Russian. This reflects the importance of Germany, France, Italy, Spain or Russia in the foreign trade relations of the Slovak Republic (Table 1).

Table 1. Share of the most important trading partners in the foreign trade of the Slovak Republic (in 2017)

\begin{tabular}{|c|l|l|}
\hline Business partner & $\begin{array}{l}\text { Import } \\
(\boldsymbol{\%})\end{array}$ & Export (\%) \\
\hline EU 28 & 66.6 & 85.5 \\
\hline From the EU: Germany & 16.8 & 20.6 \\
\hline Italy & 3.3 & 6.0 \\
\hline Austria & 3.0 & 6.0 \\
\hline France & 3.2 & 6.3 \\
\hline United Kingdom & 2.5 & 6.0 \\
\hline Spain & 1.5 & 3.0 \\
\hline Russia & 4.7 & 2.0 \\
\hline Brazil & 0.1 & 0.1 \\
\hline Mexico & 0.1 & 0.2 \\
\hline
\end{tabular}

Source: Statistical Office of Slovak Republic, 2018.

The results of our survey confirm that English is the most important foreign language from the perspective of EU BA graduates. It is used by more than $95 \%$ of respondents. Next are German and Spanish (Figure 4). As far as German is concerned, the results of our survey confirmed that the importance of foreign languages is determined by the location of the most important business partners. Germany is 
Slovakia's largest trading partner. In addition, Austria is an important partner of Slovakia. The importance of Spanish in our survey compared to the other foreign languages mentioned is influenced by the composition of the sample, as the aim was to reach as many companies as possible that cooperate with the Spanishspeaking countries. Among these countries, most respondents worked with Spain (64\%). 29\% of respondents cooperated with at least one Latin American country (notably Mexico, Brazil, Chile, Peru, Colombia, Venezuela, Cuba), $17 \%$ with several Latin American countries and 20\% with all or most Latin American countries.

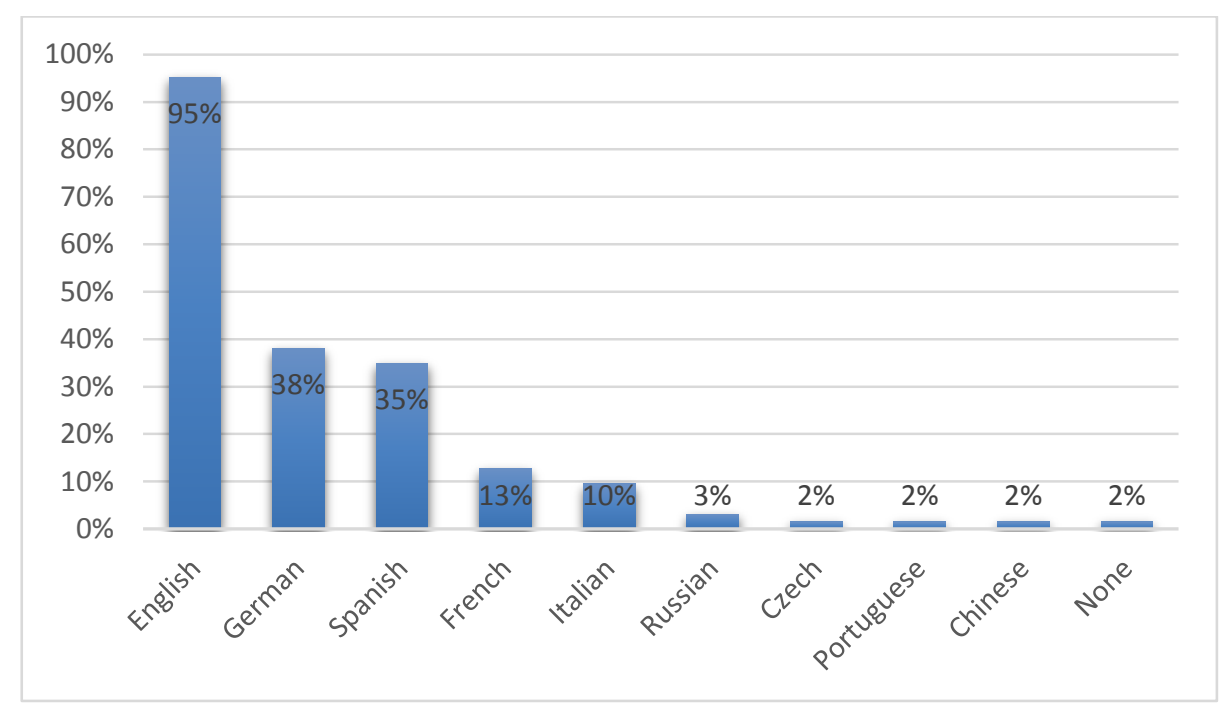

Figure 4. The most used foreign languages

In assessing the relevance of Spanish knowledge on a scale of 0 (= totally irrelevant) to 5 (= very relevant), $31 \%$ of respondents stated that Spanish is very or more relevant. On average $17 \%$ of respondents considered it relevant. For the rest of the respondents, Spanish was less relevant, little relevant or completely irrelevant. For the sake of comparison, we were also interested in assessing the relevance of other foreign language skills. This assessment also showed that English is very relevant, if not more relevant, for up to $87 \%$ of respondents. The second was German, and its knowledge was very or more relevant to $30 \%$ of respondents. Finally, $11 \%$ of respondents considered French to be very relevant. The other foreign languages mentioned (Italian, Russian, Czech) were considered very or more relevant only scarcely.

3. The importance of specific language competence and proficiency level of the Spanish language

The significance of individual language competencies or topics was measured on a scale of 0 (= not fully relevant) to 5 (= very relevant). An overview is given in Table 2 . We have found that the most important competence is speaking, which is considered "more" relevant. The writing skills compared to speaking skills achieved a slightly lower ranking of relevance, but the respondents still regard it as "more" relevant. Common vocabulary knowledge gained an average rating of 4.1 compared to professional vocabulary which received an average grade of 3.8 .

Table 2. Employers' assessment of language competencies and knowledge

\begin{tabular}{|l|c|}
\hline Language Competence / Subject & Average evaluation \\
\hline Oral communication & 4.2 \\
\hline Written communication & 3.8 \\
\hline Common vocabulary & 4.1 \\
\hline Professional vocabulary & 3.8 \\
\hline Translation competence & 2.5 \\
\hline Interpreting competence & 2.1 \\
\hline Intercultural knowledge & 2.9 \\
\hline Knowledge of history, culture of Spain & 1.1 \\
\hline Knowledge of political affairs in Spain & 1.2 \\
\hline Knowledge of social situation in Spain & 1.3 \\
\hline Knowledge of political affairs in Latin America & 1.2 \\
\hline Knowledge of the history of Latin America & 1.0 \\
\hline
\end{tabular}


Respondents had the opportunity to complete other language competencies or topics they consider important. 38\% of respondents used this option. The most frequently mentioned were the terminology of business, finance, banking, accounting, taxes, business, marketing, controlling, international trade, administration, law, IT or technology. Respondents recommended, for example, active work with professional journals during the lessons. The ability of graduates to converse and make presentations in a foreign language should also be strengthened. Last but not least, graduates should be able to write business letters and have the ability to handle correspondence in general as well as other formal documentation.

In addition to identifying important language skills and competencies, we also examined the level of proficiency in the Spanish language the job seeker should master. Respondents could mark any of levels A1 to $\mathrm{C} 2$.

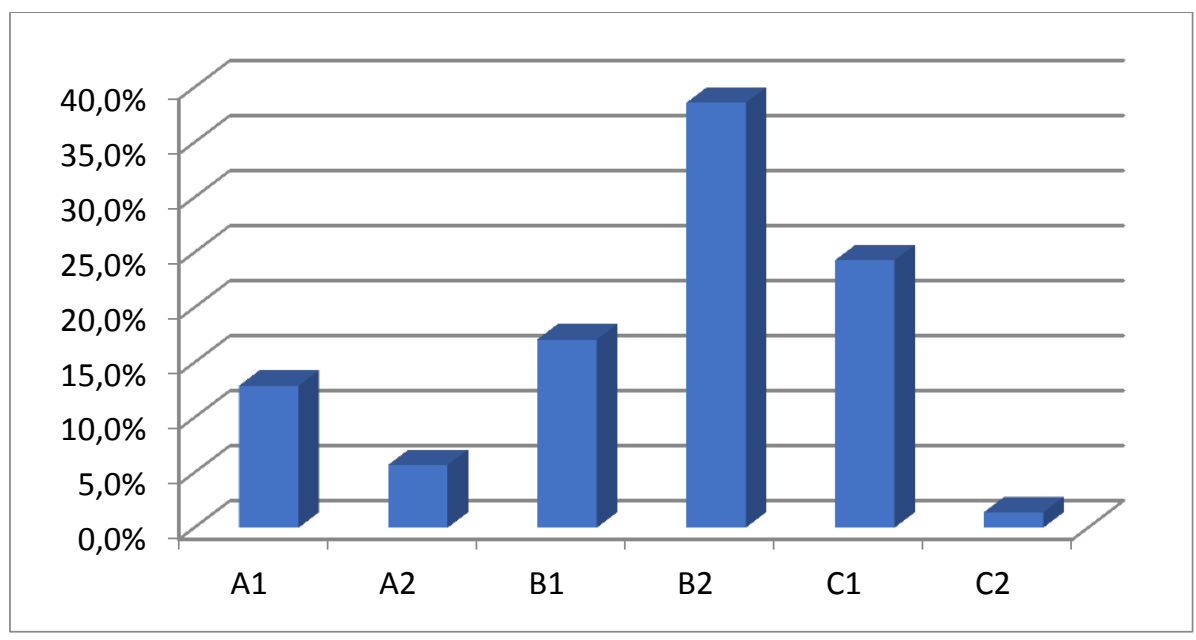

Figure 5. Employer Level Requirements for Spanish

Legend: A1 (beginner), A2 (intermediate), B1 (advanced), B2 (fluent), C1 (proficient in professional language and terminology), $\mathrm{C} 2$ (native speaker level)

Figure 5 shows that levels B2 and $\mathrm{C} 1$ are the most frequent. While level B2, fluent speaking employees, are required by almost $39 \%$ of respondents, knowledge of professional language and terminology is required by almost $25 \%$ of respondents. At the same time, the results show that up to $13 \%$ of respondents are sufficient to master Spanish at the beginner's level.

Our results can be compared with the results of a study on labour market demand for foreign language skills in EU 28 countries (European Commission, 2015), according to which the job seekers are expected to have acquired $\mathrm{B} 1$ to $\mathrm{C} 2$ level as far as the first foreign language is concerned. In the case of the second most widely used foreign language, a lower level of B1 to B2 is sufficient. In general, higher demands are placed on the level of speaking than on the level of writing. While only a fifth of the respondents required a low level of speaking skills, almost a third of the respondents required low written skills.

\section{Assessment of the language competencies of EU BA graduates and employers' expectations}

In the next part, we focused on the evaluation of the EU BA graduates knowledge of foreign languages, especially Spanish, by companies or institutions that have employed EU BA graduates over the last 5 to 10 years. Respondents were allowed to score from 1 (= excellent) to 5 (= insufficient). The average grade awarded was 2.6 (= good). The highest percentage was rated 2 (= very good) and 3 (= good). Altogether, this share was $60 \%$. The results show that there is considerable scope for improving the language skills of EU BA graduates.

Respondents were able to provide an answer to an open question, what they expect from EU BA graduates regarding foreign language skills. 68\% of respondents used this option. Of these, most (almost $30 \%$ ) would expect fluency in communication in a foreign language. For $27 \%$ it is important to master terminology and language. Ability to communicate with a foreign partner, respectively the ability to speak was reported as the third most common expectation (21\% of responses). Expectations of good writing or knowledge of economic correspondence accounted for $16 \%$ of the answers. In addition, expectations were raised with regard to foreign language presentation skills, grammar skills and overall willingness to learn and ability to learn quickly. In responses, some of the respondents also made specific recommendations on how to improve language courses at EU BA. First, there are the proposals to extent foreign language teaching during the whole period of study. Currently, foreign languages are taught 2 or 3 semesters in the Faculties of 
Commerce, Economic Informatics and National Economy, 6 or 8 semesters in the Faculty of International Relations (depending on whether it is the first, second or third language). At the Faculty of Applied Languages, two languages are studied in bachelor's and master's study programmes. English that is compulsory and German, Spanish or French. Furthermore, the teaching of vocational subjects in foreign languages should be strengthened.

\section{Conclusions}

The following conclusions are drawn from our study. From the point of view of employers of university graduates of economic and managerial specialisation in Slovakia, English language skills are the most necessary to be successful on the labour market. It is required by up to $95 \%$ of employers. We have confirmed the validity of the conclusions of other studies, which were carried out in a broader context, for all EU countries or for all employees in Slovakia. We have examined specifically the requirements for EU BA graduates. However, knowledge of English is a minimum requirement of employers. Knowledge of at least two foreign languages is often required. German, French, Italian and Spanish are most often required as the second foreign language.

As far as specific language competencies and knowledge are concerned, employers' expectations are based on the positions of EU BA graduates. The most common positions are in the fields of sales, marketing and logistics. This is followed by finance and accounting, management and project management, administration and analytical positions. From the employers' point of view, the most important competence is fluent oral communication skill in a foreign language. According to our results, however, written speech is almost as relevant as oral communication. Compared to other employers, it can be observed that employers' requirements for EU BA graduates are higher in the area of written expression. In particular, the ability to formulate business or other correspondence is required. Finally, our expectations that EU BA graduates should master vocabulary, especially in the areas of business, finance, banking, accounting, taxes, business, marketing, controlling and international trade, have been confirmed. The corresponding levels of foreign language proficiency are B2 (fluent) and C1 (proficiency in language and terminology). These levels are required by $64 \%$ of employers. Employers' assessment of the real language competencies of EU BA graduates has shown that EU BA needs to be strengthened in the preparation of foreign language skills. The ability of conversation and presentation skills in a foreign language should be improved. Emphasis should be placed on economic and management terminology.

The results of our research will be used in the preparation of a digital university textbook of Spanish language intended for the needs of teaching at EU BA or other universities of economic and managerial orientation in Slovakia. This textbook will respond to the requirements of professional practice and the needs of today's changing society, whether in economic, technological or social development. As it will be a digital textbook, it will be able to be easily and flexibly changed and updated in such a way that a questionnaire survey is repeated after a certain period (e. g. every 4 years).

Our results can also serve as a basis for the writing of other language textbooks, other didactic materials or, generally, the content of economic and managerial education.

We consider the contribution of our research in improving the link between the higher education curriculum and the real needs of the economy and the labour market. It also contributes to better employability of university graduates in Economics and Management in the labour market.

\section{Acknowledgements}

This paper is a part of a research project of the Ministry of Education, Family and Sports of the Slovak Republic KEGA (in the period 2018 - 2020) No. 1/0897/17: "Innovation of Language Training for Economists, Diplomats and Cultural Mediators - digital textbook of Spanish language oriented on professional practice"

\section{References:}

Abregova, A.V., Kenetova, R.B., Bitokova, S.Kh., Cheprakova, T.A., \& Sheriyeva, N.G. (2018). Types of conceptual organization of word combinations with a colour component in modern business English. XLinguae, 11(3), 126-135. Retrieved from http://xlinguae.eu/2018_11_03_12.html

Baláž, P., Škorvagová S., Zábojník, Hamara, A., S., Sopková, G., Szakalová, Z., ... Kučerová, G. (2012). Výskum uplatnenia absolventov inžinierskeho a doktorandského štúdia Obchodnej fakulty Ekonomickej univerzity v Bratislave, zvýšenie ich kvality a odbornej pripravy [Research on employability of higher education graduates at the Faculty of Commerce, University of Economics in Bratislava, improvement of the quality and of the professional training]. Bratislava, Slovakia: University of Economics in Bratislava, Faculty of Commerce.

European Commission (2015). Study on foreign language proficiency and employability. Retrieved from http://www.erasmusplus.sk/kniznica/publikacie/Final_Report.pdf 
Čiefová, M. \& Séresová, K. (2017). Teaching foreign languages at the University of Economics in Bratislava in connection to the needs of the labour market. Advanced Education, 8, 28-34. https://doi.org/10.20535/2410-8286.94528

De la Vega, I.N. (2016). Una propuesta de aprendizaje por proyectos en el aula de Español de Negocios [Project-Based learning proposal in a Business Spanish Course]. Foro de profesores de E/LE, 12, 179-189. https://doi.org/10.7203/foroele.1.9181

Deloitte (2018). First steps into the labour market. International survey of students and graduates. Retrieved from https://www2.deloitte.com/content/dam/Deloitte/ce/Documents/about-deloitte/ce-first-steps-into-the-labour-market2018.pdf

García Brenes, A. M. (2000). Contemporary Spain: Lessons for the Business Spanish Student. Foreign Language Annals, 33(4), 421-427. https://doi.org/10.1111/j.1944-9720.2000.tb00622.x

Grafton Slovakia (2017). Takmer polovica uchádzačov o prácu ovláda angličtinu na úrovni začiatočníka [Almost the half of the job applicants masters the English language as Beginner]. Retrieved from https://www.grafton.sk/blog/2018/03/takmerpolovica-uchadzacov-o-pracu-ovlada-anglictinu-na-urovni-zaciatocnika

Hrdličková, Z. (2019). Acquiring the knowledge and important vocabulary in the area of Management in a Business English course. Lingua et Vita, 8(15), 67-77. https://linguaetvita.sk/archiv-vydani/lingua-et-vita-15-2019\#zuzana-hrdlickova

Kaštáková, E., \& Bebiaková, D. (2017). Postavenie zahraničného obchodu Slovenska v obdobi geopolitických zmien [Position of the Slovak foreign trade in the era of geopolitical changes]. Bratislava, Slovakia: Vydavatel'stvo EKONÓM.

Lesáková, D., Dzimko, M., \& Farkašová, V. (2012). Uplatnenie absolventov vysokých škôl na trhu práce [Employability of higher education graduates on the labour market]. Project coordinated by the Slovak Academic Association for International Cooperation (SAAIC). Retrieved from https://docplayer.cz/38543094-Uplatnenie-absolventov-vysokych-skol-na-trhu-prace.html.

Lopez Perez, M. V. (2013). Criterios de selección de voces para la enseñanza del español como L2 en contextos escolares [Word selection criteria in teaching Spanish as a second language in schools]. Revista de Education, Art.8, 154-176. https://doi.org/ 10.4438/1988-592X-RE-2013-EXT-245

Montanez Mesas, M. P. (2017). Creatividad en la enseñanza de español para negocios [Creativity in teaching Spanish for business]. Foro de profesores de E/LE, 13, 223-231. Retrieved from https://ojs.uv.es/index.php/foroele/article/view/10916

Novikova, E.Yu., Mityagina, V.A., \& Charfaoui, E. (2017). Pragmatics of terminological nomination: tourism management. XLinguae, 10(3), 285-299. https://doi.org/10.18355/XL.2017.10.03.23

Rizeková, I. (2018). Supporting continuity in teaching French from secondary school to the university degree. XLinguae, 11(1), 150163. https://doi.org/10.18355/XL.2018.11.01XL.13

Rodriguez Cachon, I. (2016). Observaciones en el diseño de ejercicios de expresión escrita en cursos universitarios de ELE online Spanish as a foreign language: Designing online writing exercises at university level. Foro de profesores de E/LE, 12, 219_ 227. Retrieved from https://ojs.uv.es/index.php/foroele/article/view/9185

Rusiňáková, J. (2018). English idioms - theory and practice. Lingua et Vita, 7(14), 48-55. Retrieved from https://linguaetvita.sk/archiv-vydani/lingua-et-vita-14-2018\#jarmila-rusinakova

Ružeková, V., \& Kaštáková, E. (2018). Comparison of the Visegrad group and Baltic countries in terms of multi-criteria competitiveness indicators. Studia commercialia Bratislavensia, 11(39), 91-106. Retrieved from https://of.euba.sk/www_write/files/veda-vyskum/scb/vydane-cisla/2018-01/scb0118-ruzekova-kastakova.pdf

Sánchez, A. (2014). Spanish as a foreign language in Europe: Six Centuries of Teaching Materials. Language \& History, 57(1), 5974. https://doi.org/10.1179/1759753614Z.00000000027

Sivák, R., Daňo, F., Lenghardtová, J., Lesáková, D., Strieška, L., Hanuláková, E., ... Pupala, L. (2010). Pamätnica Ekonomickej univerzity v Bratislave [Memory book of the University of Economics in Bratislava]. Bratislava, Slovakia: Vydavatel'stvo EKONÓM.

Spišiaková, M. (2018). Contemporary Spanish business language. Lingua et Vita, 7(13), 42-54. Retrieved from https://linguaetvita.sk/archiv-vydani/lingua-et-vita-13-2018\#maria-spisiakova

Statistical Office of Slovak Republic (2018). Celkový dovoz a celkový vývoz podla kontinentov a ekonomických zoskupení krajín [Total import and total export by continents and economic groupings of countries]. Retrieved from http://statdat.statistics.sk

Tareva, E.G., Schepilova, A.V., \& Tarev, B.V. (2017). Intercultural content of a foreign language textbooks: concept, texts, practices. XLinguae, 10(3), 246-255. https://doi.org/10.18355/XL.2017.10.03.20

University of Economics in Bratislava (2018). Historické mil'niky [Historical milestones]. Retrieved from https://www.euba.sk/univer zita/historia-univerzity/historicke-milniky

Ulašin, B. (2016). Appelativization of commercial marks: Slovak-Spanish differences. Lingua et Vita, 5(10), 28-34. Retrieved from https://linguaetvita.sk/archiv-vydani/lingua-et-vita-10-2016\#bohdan-ulasin

Varela Cano, D.P. (2016). Communicative skills, elements affecting development. Lingua et Vita, 5(10), 153-160. Retrieved from https://linguaetvita.sk/archiv-vydani/lingua-et-vita-10-2016\#diana-patricia-varela-cano 